\title{
越波低減浮体パネルの動的挙動に関する \\ 多相流数值シミュレーション \\ MULTIPHASE FLOW SIMULATION OF DYNAMIC BEHAVIOR OF FLOATING PANEL FOR WAVE OVERTOPPING REDUCTION
}

\author{
川崎浩司 1 ・Han Dinh Ut ${ }^{2}$ ・松野哲弥 3 ・福本 正 4 \\ Koji KAWASAKI, Han Dinh Ut, Tetsuya MATSUNO and Tadashi FUKUMOTO \\ 1正会員 博 (工) 名古屋大学准教授 大学院工学研究科（广464-8603 名古屋市千種区不老町） \\ 2 修(工) 名古屋大学大学院工学研究科（广464-8603 名古屋市千種区不老町） \\ 3 学生会員 学(工) 名古屋大学大学院工学研究科 ( $4464-8603$ 名古屋市千種区不老町) \\ 4西松建設(株)技術研究所（广105-8401 東京都港区虎ノ門1-20-10)
}

\begin{abstract}
In this study, the dynamic behavior of a floating panel, which is installed in front of an upright seawall for wave overtopping reduction, was numerically investigated by utilizing a multiphase flow model 'DOLPHIN-3D' with solid-gas-liquid phase interaction. The validity of the model was confirmed through the comparison between the numerical results and experimental ones in terms of the water surface elevation in front of the seawall and the floating panel motion. A good agreement between the numerical results and experimental ones revealed that the model is capable of reproducing the interaction of waves and a floating body with high accuracy. A POV-Ray interface system was also developed as a three-dimensional computer graphics system which makes it easy to understand wavestructure interaction phenomena.
\end{abstract}

Key Words : Multiphase flow simulation, Wave overtopping, Floating panel, Dynamic behavior

\section{1. 序論}

近年，地球温暖化に伴う海面上昇，台風勢力の増 大が懸念され，高潮，高波による越波災害へのさら なる対策が求められている。しかしながら，越波被 害を完全に防ぐためには，護岸の新設，天端高の嵩 上げなどの大規模な対策が必要となり，全ての沿岸 域で実施することは財政的に困難である。そこで， 川崎・笹田 ${ }^{1)}$ は既設護岸に直角二等辺三角形状の越 波対策工を付加する工法を提案し, 護岸の新設を必 要としない工法により建設コストの削減が試みられ ている。一方で, 沿岸整備では, 沿岸防災を最優先 したことにより，沿岸域の環境は悪化し，次第に環 境面の改善が叫ばれるようになった。そして，天端 高を低く抑えることで，沿岸域の景観，親水性を損 なわない護岸の提案もされている。このように，防 災面だけでなく, 海岸環境の整備と保全, 公衆の海 岸の適正な利用などの複合的視点による沿岸防災構 造物の整備が進められている.

上記の背景を鑑み，著者ら ${ }^{2)}$ は，既設直立護岸の 前面に浮体パネルを設置する越波対策工法を提案し た。これは，高潮，高波襲来時に，浮体パネルが自 然外力である浮力により水面変動に追随することで, 護岸背後へ水塊が流入するのを防ぐ護岸形式である. 天端高嵩上げと同等の効果が期待され，天端高を嵩
上げした場合に比べ，景観をあまり阻害しない。ま た，既設護岸に浮体パネルとそれを囲むフレームを 付加するだけでよいため, 維持管理が容易な構造物 であり, 陸域の改変, 埋め立ての必要がなく環境へ の影響が少ない。また，水理模型実験を実施するこ とにより, 浮体パネルは高い越波低減効果を有する ことを明示した。一方，移動する浮体パネルの作用 波圧を明らかにすることは移動物体の設計面で重要 であるが，水理模型実験では測定が困難であり，数 值解析による検討が有効である。著者ら ${ }^{3), 4)}$ は，沿 岸域の複雑な現象を解明するために，3次元固気液 多相乱流数值モデルDOLPHIN-3D（Dynamic numerical model Of muLti-Phase flow with Hydrodynamic INteractions-3 Dimension version）を開 発した。しかしながら，本モデルは水理模型実験へ の適用例が少ない上，水理模型実験で測定が困難な 浮体パネルの作用圧力に関する検討を行うには，ま ず浮体パネルの動的挙動を高精度に再現可能である ことを確認する必要がある。

本研究では, 浮体パネルの動的挙動を精微に再現 できるように多相乱流数值モデルDOLPHIN-3Dの剛 体解析法を改良するとともに，数值計算と水理模型 実験の比較から，DOLPHIN-3Dの妥当性・有用性を 検証することを目的としている. 


\section{2. 多相乱流数値モデル DOLPHIN-3D}

\section{（1）基礎方程式}

本研究で使用する3 次元多相乱流数值モデル DOLPHIN-3Dの支配方程式は, 圧縮性粘性流体に対 する質量保存式(1), Navier-Stokes方程式(2), 圧力 方程式(3), 密度関数の移流方程式(4), バロトロ ピー流体に対する状態方程式(5)から構成される.

$$
\begin{gathered}
\frac{\partial \rho}{\partial t}+\frac{\partial\left(u_{j} \rho\right)}{\partial x_{j}}=\rho q \\
\frac{\partial u_{i}}{\partial t}+u_{j} \frac{\partial u_{i}}{\partial x_{j}}=-\frac{1}{\rho} \frac{\partial p}{\partial x_{i}}-g_{i}+\frac{f_{s i}}{\rho} \\
+\frac{\partial}{\partial x_{j}}\left(-\tau_{i j}+2 \frac{\mu}{\rho} S_{i j}\right)-D_{i} u_{i} \\
\frac{\partial p}{\partial t}+u_{i} \frac{\partial p}{\partial x_{i}}=-\rho C_{l s}^{2}\left(\frac{\partial u_{i}}{\partial x_{i}}-q\right) \\
\frac{\partial \phi_{I}}{\partial t}+u_{i} \frac{\partial \phi_{I}}{\partial x_{i}}=0 \\
\rho=f(p) \\
q=\left\{\begin{array}{l}
0 \\
q^{*}\left(x \neq x_{s}\right)
\end{array}\right.
\end{gathered}
$$

ここで， $\rho$ は流体の密度， $t$ は時間， $u_{i}$ は各方向の速 度ベクトル， $x_{i}$ は座標ベクトル， $q$ は造波ソースの わき出し強さであり, 式(6)に示されるように造波 側線 $x=x_{s}$ で $q^{*}$ の值をもつ. $p$ は圧力, $g_{i}$ は重力加速度 ベクトル， $f_{s i}$ はBrackbill et al. ${ }^{5}$ が考案した CSF

(Continuum Surface Force) モデルによる表面張力, $\tau_{i j}$ はSalvetti and Banerjee ${ }^{6}$ が開発したdynamic二変数 混合モデルDTM (Dynamic Two-parameter Mixed model）に基づくLES（Large Eddy Simulation）モデ ルによるSGS（Sub Grid Scale）応力， $\mu$ は粘性係数, $S_{i j}$ はひずみ速度テンソル， $D_{i}$ はエネルギー減衰領域 における係数， $C_{l s}$ は局所音速を示す。また， $\phi_{I}$ $\left(I=1 \sim 3 ; \phi_{1}\right.$ : 固相， $\phi_{2}$ : 液相， $\phi_{3}$ : 気相 $)$ はある 計算格子における密度関数であり, $\phi_{1}+\phi_{2}+\phi_{3}=1\left(0 \leq \phi_{I} \leq 1\right)$ の関係を満たす.

\section{（2）計算アルゴリズム}

本モデルは, 時間分離解法により, 前述した Navier-Stokes方程式, 圧力方程式を移流段階, 非移 流段階に分割することで高精度に解析可能である. 計算フローチャートを図-1に示す。はじめに初期条 件・境界条件の設定を行う。ついで, 波高・周期の 入力条件から造波ソースを設定した位置における ソースのわき出し強さを計算する. その後, 流体の 流速 $u_{i}$, 圧力 $p$ の移流段階計算に, CIP (Constrained Interpolation Profile) 法7),8)を適用する。そして，算 定された移流段階後の各物理量を用いて，圧縮性・
非圧縮性流体を同時に解析可能な拡張 SMAC

（Simplified Marker And Cell）法により非移流段階 計算を実施する。なお, 気液界面に生じる表面張力 の影響はCSFモデルにより算定し, 乱流量について はLESモデルにより評価する. 非移流段階計算後, 更新された流速を使用し, 密度 $\rho$ を保存保証型CIP 法であるCIP-CSL2 (Constrained Interpolation Profile Conservative Semi-Lagrangian of second-order) ${ }^{99}$ によ り計算する. 前述した流動解析を固気液全相に対し て行った後, 固相内部の圧力を使用して複数剛体の 運動解析を実施する. その後, 全相の密度関数 $\phi_{I}$ の 移流計算を，剛体速度の流体場への影響を考慮した 流速を用いてCIP法により実施する。密度関数 $\phi_{I}$ の 移流計算後, 最終的に各物理量を更新し, 次の時間 ステップヘ移行する．上述した計算を時間ステップ ごとに繰り返し行うことで, 本モデルでは複数剛体 の動的挙動を含む固気液多相乱流場を精微に数值解 析することができる.

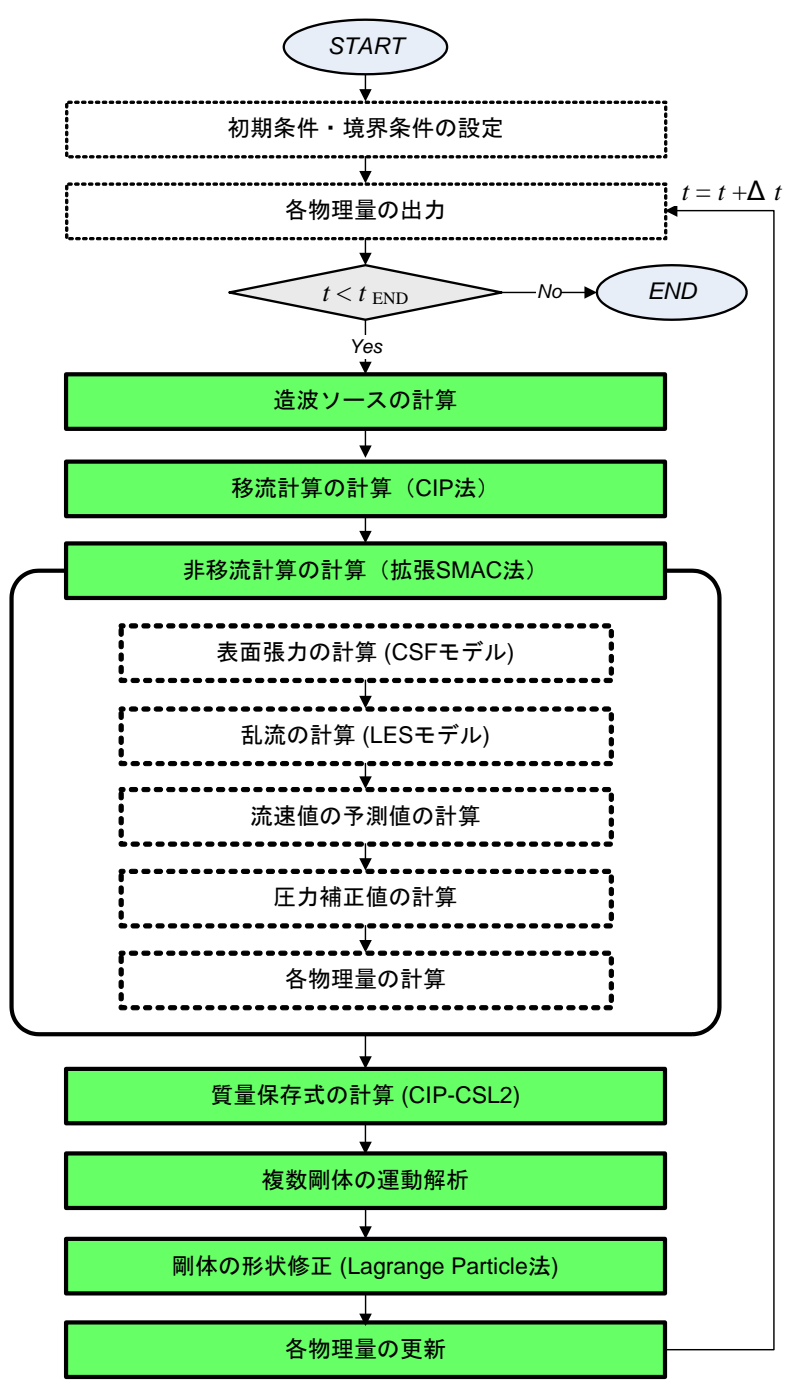

図-1 計算フローチャート

\section{（3）剛体解析法}

本モデルで使用する剛体解析法では，剛体の運動 をXiao et al. ${ }^{10)}$ と同様に取り扱っている. 固相群は 
剛体であり，その運動形態は並進運動と回転の両方 から構成されるという仮定の下で，固相を高粘性流 体とみなして流動解析を行う。水理模型実験では, フレームにより, 浮体パネルの運動を鉛直方向のみ に規定している。そのため, 数值計算では, 浮体パ ネルの鉛直方向の運動方程式だけを解くこととし, 回転運動はないものとする。また, 水理模型実験で は，フレームと浮体パネルの間には若干の隙間があ り, 水平方向の微小な挙動により, 浮体パネルとフ レーム間の衝突，摩擦が発生している。しかしなが ら，現在の本モデルでは，物体間の衝突力を扱うこ とができない。そこで，簡易的な方法として，衝突 の影響を運動方程式に抵抗として導入する. 水理模 型実験において, 浮体パネルの速度が大きいほど衝 突は顕著にみられたため, 速度に比例する抵抗を導 入することで浮体パネルの動的挙動の高精度化を図 る.

速度抵抗を導入した剛体の並進運動計算を以下に 示す. 流動解析を行い, 得られた固相内部の圧力を 用いて，Newtonの第2法則より，剛体内部の加速度 を求める。ついで, 剛体の重心位置での加速度を算 定し, 剛体に作用する力を従来の剛体並進運動の計 算で求める。そして, 式(7)に示す速度抵抗を考慮 した運動方程式を新たに用いる。

$$
M_{l} \frac{d w_{l}^{n+1}}{d t}+b w_{l}^{n+1}=F^{*}
$$

ここで， $M_{l}$ は計算領域における剛体 $l の$ 総質量， $b$ は 速度抵抗， $w_{l}$ は剛体 $l$ 重心における速度，F洞体 に作用する外力である。また $n+1, *$ *時間ステッ プであり，*は $n, n+1$ の間の時間ステップである. また， $w_{l}^{n+1}$ の值は未知であるため, 式(8)に示す陰 解法の時間差分スキームであるクランク・ニコルソ ン法を用いる。

$$
w_{l}^{n+1}=w_{l}^{n}+\left(\frac{d w_{l}^{n}}{d t}+\frac{d w_{l}^{n+1}}{d t}\right) \frac{\Delta t}{2}
$$

ここで， $\Delta t$ は計算間隔である.

ついで，式(7)に式(8)を代入し，速度に関する $n+1$ の時間ステップの項を消去する. そして, 式を 変形することで, 加速度は式(9)から求められる.

$$
\frac{d w_{l}^{n+1}}{d t}=\frac{-b\left(w_{l}^{n}+\frac{d w_{l}^{n}}{d t} \frac{\Delta t}{2}\right)+F^{*}}{M_{l}+b \frac{\Delta t}{2}}
$$

\section{（4）POV-Rayによよる可視化}

現在, 数值解析は, 海岸工学分野で海象現象の解 明に大きな役割を担うようになってきた。ささらに， 計算結果を沿岸域の防災に役立てるためには，海岸 工学を専門としない人にも沿岸域の現象が容易にイ
メージできるような図示が必要である。そこで, 本 研究では，計算結果をリアリティのある映像とする ために, POV-Ray (Persistence Of Vision Raytracer) による可視化を行う。POV-Rayとは，3次元グラ フィックを描くレイトレーシングソフトウェアであ り, 光の屈折, 反射を現実に近い形で表現が可能で ある。本研究では, DOLPHIN-3Dによる計算結果を 簡易に図示できるように，POV-Ray用のインター フェースの構築を行った.

POV-Ray用のインターフェースによる描画手順を 以下に示す. まず, 計算格子数, 変数の数を設定し たファイルを読み込み, 図-2に示すインターフェー スプログラムを起動する. 入力ファイルに，描画す る数值計算結果のデータを入力する. ついで, 変数 設定で読み込んだ変数の材質を定義する。ここで, 液相の材質は，waterで定義され，海の色合いを表 現するために，水深ごとに色を変化させた，その後， カメラの位置をプレビューにより確認を行い, 決定 する. カメラ位置と注視点を変化させることで様々 な角度から現象が確認でき, より効果的に画像を見 せることが可能である。そして, 画像サイズ, 出力 形式を決め，描画を行う。

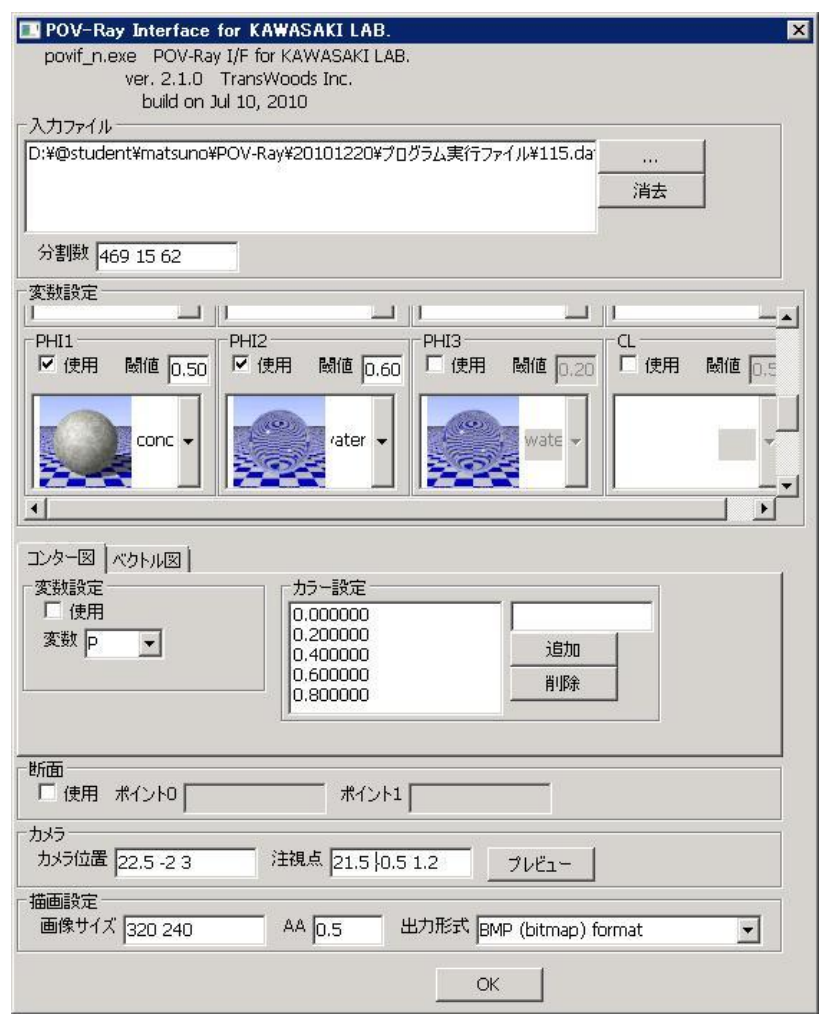

図-2 POV-Ray用インターフェース

\section{3. 水理模型実験}

名古屋大学大学院工学研究科社会基盤工学専攻が 所有する断面2次元造波水路（長さ $30 \mathrm{~m}$, 幅 $0.7 \mathrm{~m}$, 高さ $0.9 \mathrm{~m}$ ）を用いて水理模型実験を行った。実験 模型の縮尺を $1 / 20$ とし, 浮体パネルを直立護岸前面 
に設置した。浮体パネルはアクリル製の直方体で, 高さ $0.20 \mathrm{~m}$, 厚さ $0.03 \mathrm{~m}$, 幅 $0.66 \mathrm{~m}$, 密度 $500 \mathrm{~kg} / \mathrm{m}^{3}$, 喫水は $0.10 \mathrm{~m}$ である。また，図-3に示す高さ $0.25 \mathrm{~m}$ のアルミ製フレームによって, 浮体パネルの挙動は 鉛直方向のみに規定した。

波浪条件は，周期を $2.24 \mathrm{~s}$ に固定し，波高を $0.04 \mathrm{~m}$, $0.10 \mathrm{~m}$ と 2 種類に変化させた。波高 $0.04 \mathrm{~m}$ では，浮体 パネルの挙動に着目した水理模型実験であり, 非越 波条件である。一方で, 波高 $0.10 \mathrm{~m}$ は越波条件であ る.波浪条件はそれぞれ現地換算すると，周期は $10 \mathrm{~s}$, 波高は $0.8 \mathrm{~m} ， 2.0 \mathrm{~m}$ に相当する。なお，越波低 減浮体パネルが設置される場所は直立護岸前面であ ることから，実用化された際，主に内湾部での施工 が予想され，波高は2.0mほどに設定した。

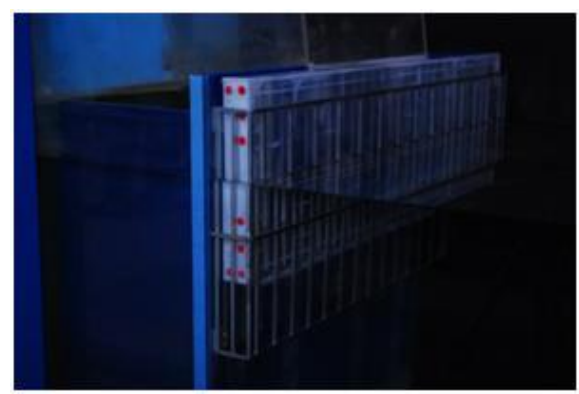

図-3 浮体パネル設置状況

\section{4. 浮体パネルの動的挙動に関する数值解析}

\section{(1) 計算条件}

本研究では，3次元モデルDOLPHIN-3Dを用いる が，水理模型実験ではほぼ鉛直2次元的現象である ことを確認しているため, 奥行き方向の計算格子数 を1，格子幅を $0.04 \mathrm{~m}$ とて，2次元的に数值計算を 実施した。

波浪条件は，上述した2種類である。図-4に示す ように，波高ごとに計算領域を設定した。静水深は $0.425 \mathrm{~m}$ であり, 浮体パネル前面W2にて水面変動を 計測した。開境界処理として，沖側に約 2.25 波長分 の減衰領域を配置し, 波高 $0.10 \mathrm{~m}$ の条件では, 護岸

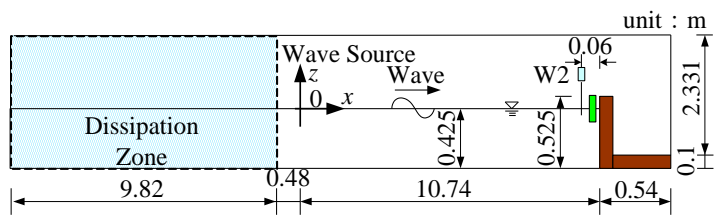

(a) 波高 $0.04 \mathrm{~m}$ の条件における計算領域

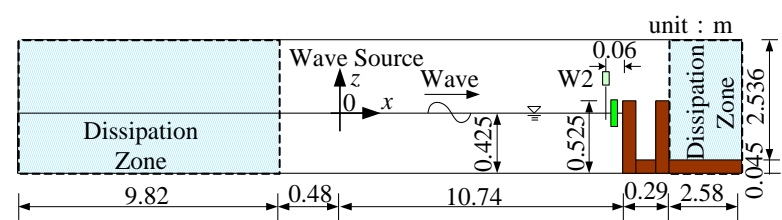

(b) 波高 $0.10 \mathrm{~m} の$ 条件における計算領域

図-4 計算領域
背後で発生する渦による気相の過剰な流速を抑える ために，護岸背後にも減衰領域を配置した。各波浪 条件の計算条件を表-1に示寸。 $x, z$ 方向の格子幅は, 境界付近での流速の発生を抑えるために, 領域の上 端, 減衰領域内の端に近づくにつれて 1.05 倍ずつ大 きくした. また, 浮体パネル周辺では, 水理現象を 精微に解析するため, 格子幅を $5 \mathrm{~mm}$ と細かく設定 した。

速度抵抗 $b$ 值を，波高 $0.04 \mathrm{~m}, 0.10 \mathrm{~m}$ に対してそ れぞれ $0.7 ， 1.0$ と設定した。速度抵抗 $b$ の值の決定 方法を以下に示す。まず，波高ごとに入射波周期を 変化させた数值計算を実施した。 その結果，入射波 周期が短くなるにつれ，水理模型実験と浮体パネル の挙動に大きな差が生じた。そこで，周期の短い条 件で $b$ の值を変化させ, 高い再現性を有する值を各 波高における速度抵抗の值として決定した。

表-1 計算条件

\begin{tabular}{c|c|c}
\hline & 波高 $0.04 \mathrm{~m}$ & 波高 $0.10 \mathrm{~m}$ \\
\hline 計算領域 & $21.58 \times 2.431 \mathrm{~m}$ & $23.91 \times 2.581 \mathrm{~m}$ \\
\hline 格子数 & $482 \times 141$ & $510 \times 192$ \\
\hline 格子幅 & $\Delta x=0.005 \sim 0.506 \mathrm{~m}$ & $\Delta x=0.005 \sim 0.506 \mathrm{~m}$ \\
\hline 計算間隔 & $\Delta z=0.005 \sim 0.093 \mathrm{~m}$ & $\Delta z=0.005 \sim 0.093 \mathrm{~m}$ \\
\hline
\end{tabular}

\section{(2) 再現計算}

越波低減浮体パネルの動的挙動に関する数值解析 を実施した。波高 $0.04 \mathrm{~m}, 0.10 \mathrm{~m}$ の条件におけるW2 の水面変動 $\eta$, 浮体パネルの挙動 $z$ の時系列変化につ いて, 水理模型実験との比較をそれぞれ図-5, 図-6 に示す。なお, 実線が計算結果, 丸印が実験結果で ある。図-5(a)をみると, 護岸からの反射波の影響 により重複波が生じ，入射波高 $0.04 \mathrm{~m}$ に対して護岸 前面波高が約2倍になっていることがわかる。また， 計算結果は, 水理模型実験における水面変動を精度 よく再現しているといえる。図-5(b)から, 本モデ ルは浮体パネルの上下運動を概ね再現している。ま た, 両図より, 水面変動と浮体パネルの挙動の時系 列変化を比較すると, 浮体パネルは水面変動をよく 追随していることが実験波形と計算波形の両方から 認められる。一方, 図-6(a)より，計算結果，実験 結果ともに，有限振幅波の特徵である波峰が尖り， 谷が平坦になる上下非対称な波であることが確認で きる。また，入射波高 $0.04 \mathrm{~m}$ の場合と同様に，入射 波高 $0.10 \mathrm{~m}$ に対して護岸前面波高が約2倍になって いる。また，入射波高 $0.10 \mathrm{~m}$ における浮体パネルの 挙動を示す図-6(b)から, 浮体パネルの挙動は, 水 面変動と同様に上下非対称な波形となっていること がわかる、計算結果は，実験結果を概ね再現できて いるものの, 浮体パネル下降時点での挙動に若干の 差異がみられた。この挙動の差異は, 浮体パネルと フレームの衝突によるものと考えられる. 数值計算 では，衝突を速度抵抗として考慮したため，水理模 型実験における浮体パネル下降時の挙動を再現でき なかった可能性がある。図-6(a), (b)の波形の時系 


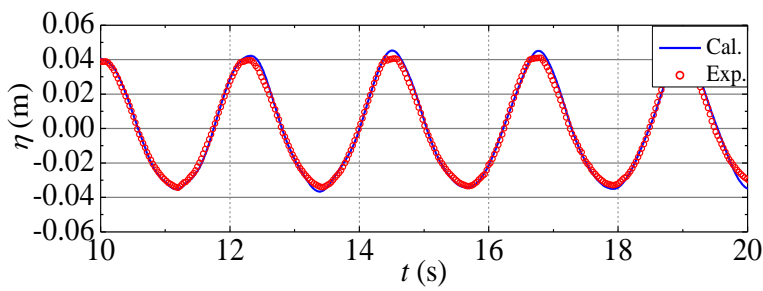

(a) 浮体パネル前面における水面変動

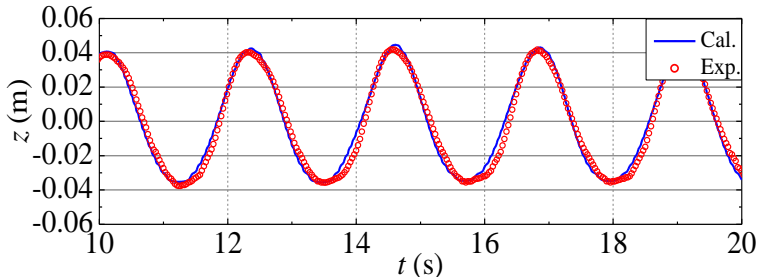

(b) 浮体パネルの動的挙動

図-5 波高 $0.04 \mathrm{~m}$ における実験と計算結果の比較

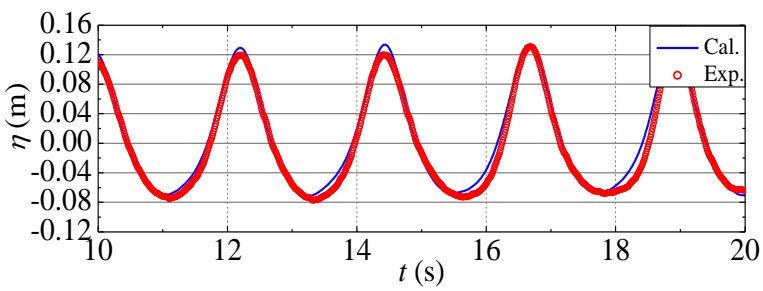

(a) 浮体パネル前面における水面変動

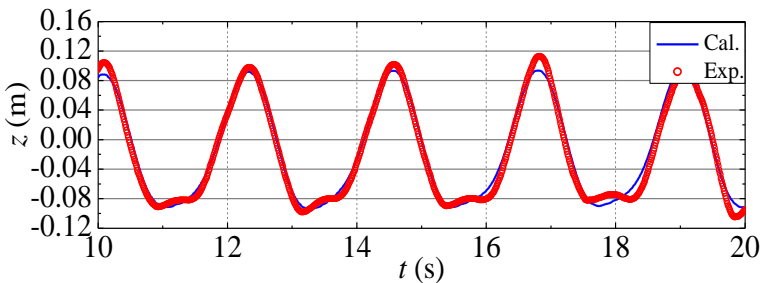

(b) 浮体パネルの動的挙動

図-6 波高 $0.10 \mathrm{~m}$ における実験と計算結果の比較
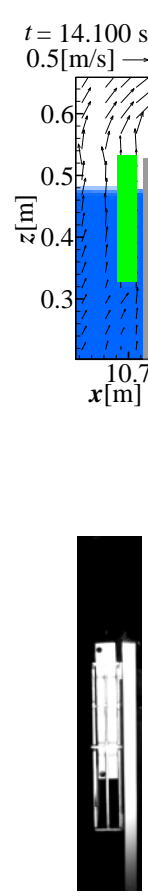
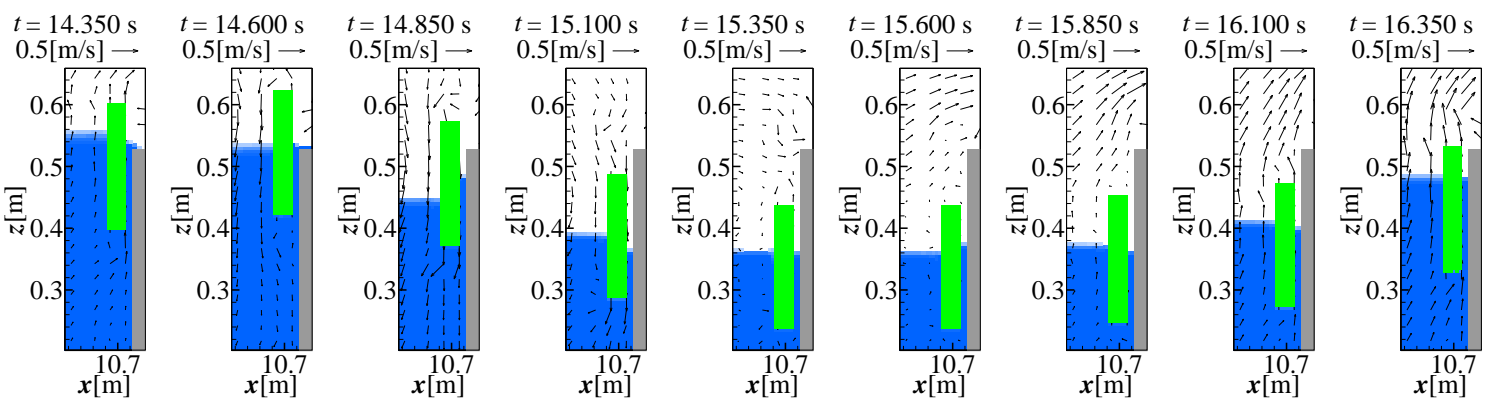

(a) 計算結果
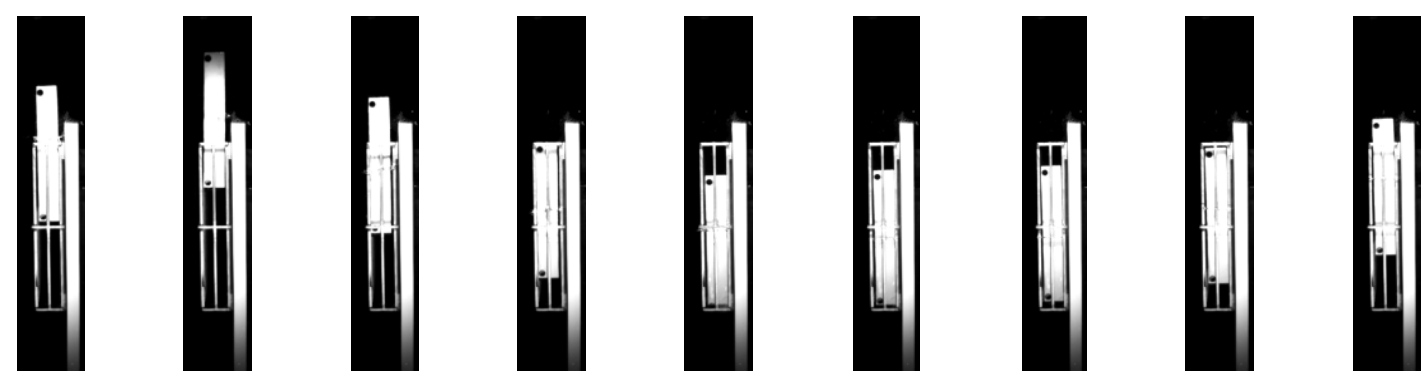

(b) 実験結果

図-7 浮体パネルの動的挙動

列変化を比較すると，浮体パネルは，水面変動と同 位相で上下運動していることがわかる。したがって， 本条件の範囲内では, 浮体パネルは水面変動に対し て高い追随性をもつため，水面変動に近い波形とな り, 図-5と図-6で波高による浮体パネルの挙動の違 いが生じたと考えられる。

波高 $0.10 \mathrm{~m}$ の条件について，浮体パネルの挙動を 可視化した結果を図-7に示す。なお，図-7(a)は $0.25 \mathrm{~s}$ の間隔で可視化した計算結果であり，図-7(b) は実験結果における動画のスナップショットである. 図-7(a), (b)の比較から, 計算結果は, 水理模型実 験における浮体パネルの上下運動を表現できている といえる. 図-6(b)に示寸浮体パネルの挙動の時系 列変化のように, 計算結果と実験結果における浮体
パネルの上下運動は, 浮体パネル上昇停止時より下 降停止時の方が長いことが図-7からも確認できる. 時刻 $t=14.350 \mathrm{~s}$ では，浮体パネルが上昇することで, 護岸背後への水塊の進入を防御していることがわか る。一方で, 浮体パネルと護岸の隙間から僅かな越 流がみられる。水理模型実験においても，同様の越 波が確認されており, 浮体パネルの挙動に影響を与 えずに隙間を塞ぐなどの対策が必要である。また， 計算結果から, 波と移動物体と気相の相互作用が良 好に解析されていると判断される.

以上の結果から, 速度抵抗を導入した3次元多相 乱流数值モデルDOLPHIN-3Dは浮体パネルの動的挙 動，護岸前面の水面変動を高精度に再現可能である といえる. 

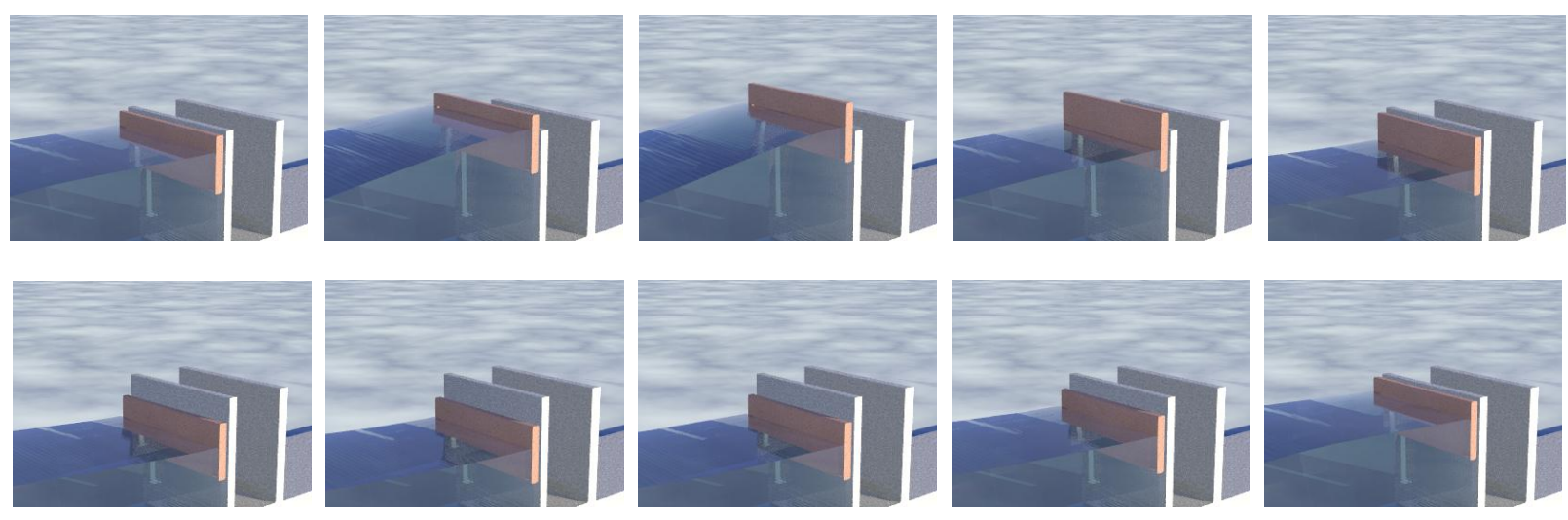

図-8 POV-Rayによる3次元描画

\section{(3) POV-Rayによる3次元描画}

図-8は，波高 $0.10 \mathrm{~m}$ におり浮体パネルの上下運 動の様子をPOV-Rayによって3次元的に描画したも のである. 水面による光の反射, 現実に近い水の色 合い, 光の屈折により浮体パネルが水中と空気中で 色が異なることがわかる．また，浮体パネルと背後 の護岸の色を変えることにより, 浮体パネルが設置 されている状況がイメージしやすくなっている。さ らに, 浮体パネルが越波を防ぐ様子が視覚的に理解 できる.

以上より, POV-Ray用インターフェースは, 沿岸 域の現象に関するリアリティのある描画が可能であ り, 浮体パネル周辺の物理現象の把握・視覚的な理 解に役立つと考えられる.

\section{5. 結論}

本研究では, 浮体パネルの動的挙動の再現性を 向上させる手段として, 剛体の運動方程式に速度抵 抗の導入を行った. 水理模型実験との比較から, 浮 体パネルの動的挙動, 護岸前面の水面変動を高精度 に再現可能であるとともに, 越波低減効果を確認し た. 以上から, 3 次元多相乱流数值モデル DOLPHIN-3D の妥当性を示した. さらに, 本モデ ルによる計算結果を 3 次元グラフィックで描画する POV-Ray 用インターフェースシステムを構築した。 インターフェースシステムは, 計算結果の高度な可 視化が可能であり, 護岸周辺における水理現象の理 解に役立つといえる. そして, ソフト面の防災対策 への適用が期待される.

今後, 様々な入射波条件で計算を行い, 浮体パネ ルの応答特性に関して考察するとともに, 不規則波 作用下における浮体パネルの動的挙動についても検 討寸る必要がある. また, 浮体パネルとフレームの 衝突力を考慮できるようにモデルを改良し, 浮体パ ネルの動的挙動のさらなる再現性向上を図るととも に, 移動物体の而波設計に役立てるため, 浮体パネ
ルに作用する圧力に関しても検討する予定である.

謝辞 : 本研究の一部は, 科学研究費補助金・若手研 究(A)（研究代表者: 名古屋大学・川崎浩司, 課題 番号：21686046）であることをここに付記し，感謝 の意を表する.

\section{参考文献}

1) 川崎浩司, 笹田泰雄: 直立護岸に設置した越波対策 工の越波低減効果と作用波圧特性, 海岸工学論文集, 第 65 巻, pp.766-770, 2009.

2) 川崎浩司, 舟橋 徹, 福本 正: 浮体パネルによる 越波低減護岸の有効性に関寸る実験的研究, 土木学 会論文集 B2 (海岸工学) , Vol.B2-66, No.1, pp.741$745,2010$.

3) 川崎浩司, 中辻啓二 : 3 次元固気液多相乱流数值モデ ルの構築とその検証, 海岸工学論文集, 第 49 巻, pp.56-60, 2002.

4) 川崎浩司, 袴田充哉: 3 次元固気液多相乱流数值モデ ル DOLPHIN-3D の開発と波作用下での漂流物の動的 解析, 海岸工学論文集, 第 54 巻, pp.31-35, 2007.

5) Brackbill J.U., Kothe D.B., and C.Zemach: A continuum method for modeling surface tension, J. Computational Physics, Vol.100, pp.335-354, 1992.

6) Salvetti M.V., Banerjee S.: A priori tests of a new dynamic subgrid-scale model for finite-difference largeeddy simulations, Phys.Fluid, Vol.7, No.11, pp.2831-2847. 1995.

7) Yabe $T$, and Aoki $T$ : Universal solver for hyperbolic equations by cubic-polynominal interpolation Onedimensional solver, Computer Physics Communications, Vol.66, pp.219-232, 1991.

8) Yabe T: Unified Solver CIP for Solid, Liquid and Gas, Computational Fluid Dynamics Review 1997, 1997.

9) Nakamura, T., Tanaka, R., Yabe, T., and Takizawa, K.: Exactly conservative semi-Lagrangian scheme for multidimensional hyperbolic equations with directional splitting technique, J. Computational Physics, Vol.174, pp.171-207, 2001.

10) Xiao F, Yabe T, Ito T, and Tajima M: An algorithm for simulating solid objects suspended in stratified flow, Computer Physics Communications, Vol.102, pp.147-160, 1997. 